\title{
The Palearctic species Bembidion femoratum and Amara communis (Coleoptera: Carabidae): new records and notes on modes of introduction to North America
}

\author{
Christopher G. Majka \\ Nova Scotia Museum of Natural History, 1747 Summer Street, Halifax, Nova Scotia, \\ Canada B3H 3A6 (e-mail: c.majka@ns.sympatico.ca)
}

\begin{abstract}
The Palearctic species Amara communis (Panzer) and Bembidion femoratum Sturm were both first reported from North America in 1992. Since that time a sizeable number of additional specimens of both species have been found, which substantially expands their known range on the continent. These records are summarized herein. The possible modes of introduction of both species are discussed within the context of other introduced insects, particularly those first found in Atlantic Canada. In the case of A. communis, the many coastal localities where it occurs would seem to indicate that it was introduced in association with transatlantic marine traffic, possibly the shipment of dry ballast. In the case of $B$. femoratum, the mode of introduction is less clear. Possible associations with nursery stock, dry ballast, and the movement of aircraft are all discussed.
\end{abstract}

\begin{abstract}
Résumé-Les espèces paléarctiques Amara communis (Panzer) et Bembidion femoratum Sturm ont toutes deux été signalées pour la première fois en Amérique du Nord en 1992. Depuis lors, un nombre important de spécimens supplémentaires des deux espèces ont été récoltés, ce qui augmente considérablement leur aire de répartition connue sur le continent. On en trouvera ici la compilation succincte. La discussion porte sur les voies d'introduction de ces deux espèces dans le contexte de l'établissement d'autres insectes exotiques, particulièrement ceux signalés pour la première fois dans la région altantique du Canada. Dans le cas d'A. communis, les nombreuses localités côtières où elle se retrouve sembleraient indiquer une introduction reliée au transport maritime transatlantique, probablement dans les matériaux secs utilisés pour le ballastage. Le mode d'introduction de $B$. femoratum est moins clair; des associations possibles avec les stocks de pépinières, les matériaux secs de ballastage et les déplacements des aéronefs sont considérées.
\end{abstract}

[Traduit par la Rédaction]

\section{Introduction}

Atlantic Canada has long been recognized as a point of entry for many exotic species of beetles. The first accounts of Coleoptera from Nova Scotia are from Kirby (1837), and of 38 species reported from the province, 5 are adventive Palearctic ones. Of the 100 species of Coleoptera reported by Jones (1869), 10 are introduced Palearctic ones. Four additional species are reported in Evans (1899). Brown (1940, 1950, 1967) reported 76 Palearctic species from Atlantic Canada. Lindroth (1954, 1955, 1957, 1963) treated this topic extensively and reported many species of Palearctic Carabidae. Hoebeke and Wheeler (1996a, 1996b, 2000, 2003), Wheeler and Hoebeke (1994), Johnson (1990), and Majka and Klimaszewski (2004) reported

Received 16 May 2005. Accepted 10 August 2005. additional Palearctic species newly adventive in the region, and the topic is far from exhausted. In Nova Scotia there are 329 introduced species, constituting $14.6 \%$ of the recorded beetle fauna, while on Prince Edward Island there are 154 introduced species, accounting for $18.5 \%$ of the recorded beetle fauna (C.G. Majka, unpublished data).

There has been considerable interest in the modes of introduction of these species. Brown (1950) and Lindroth (1957) both developed a theory that ships' dry ballast was a probable source of entry of many introduced grounddwelling Coleoptera. Brown (1950) noted that large quantities of dry ballast (bulky rock, sand, and soil) were unloaded at Maritime ports during the Napoleonic Wars (1799-1815) by British vessels in search of timber at a time when Baltic ports were closed to Britain. Lindroth 
(1957) investigated this topic further, conducting (amongst other studies) extensive vegetational and faunal surveys at sites in Great Britain known to have been sources of ballast in the transatlantic shipping trade. Bousquet (1992) tabulated 23 exotic species of Carabidae known to have been introduced to North America through ports in Atlantic Canada.

Another mode of introduction was discussed by Spence and Spence (1988), who suggested that the importation of nursery stock prior to 1965 (when quarantine restrictions on the import of soil were not in force) could explain the distribution of some introduced Carabidae. In particular, they singled out species that are geographically isolated, have restricted distributions, are found in agricultural areas, and have recently been detected in areas that are well known faunistically as prime candidates for such a mode of introduction. Majka and Klimaszewski (2004) proposed four species that may have been introduced in association with the planting of tree nursery stock and drew attention to other species that may have arrived with imported livestock or garden plants. Mikkola and Lafontaine (1994) proposed that grass turf associated with shipping practices and adhering to shipping containers may have been responsible for the introduction of three species of Palearctic noctuid moths to North America.

In this context it is instructive to examine Amara communis (Panzer) and Bembidion femoratum Sturm, two species of Palearctic beetles reported for the first time in North America by Bousquet (1992). Amara communis was reported from West Quaco and Waterside, New Brunswick, in 1988, while B. femoratum was reported on the basis of records from Lawrencetown (1967) and Sydney (1983) in Nova Scotia and Saint John in New Brunswick (1988).

Bousquet (1992) hypothesized that the introduction of these species had taken place recently, possibly through the port of Saint John, and suggested that imported nursery stock could have been responsible for their origin. Since Bousquet's report, a sizeable number of additional specimens of both species have been found. These records expand the known range of both species in North America and raise questions about the mode of their introduction to the continent and their subsequent dispersal.

\section{Methods and conventions}

In the context of research on the beetle fauna of the Maritime Provinces, most of the major collections of Coleoptera in the region were examined. Specimens of both A. communis and B. femoratum were studied. Further records were provided by researchers listed in the Acknowledgements. Yves Bousquet (Agriculture and Agri-Food Canada, Ottawa) and Fritz Hieke (Institute of Systematic Zoology, Berlin) were kind enough to confirm the species determinations of many of the specimens.

\section{Collection abbreviations}

ACNS Agriculture Canada, Kentville, Nova Scotia, Canada

ACPE Agriculture Canada, Charlottetown, Prince Edward Island, Canada

CAS California Academy of Sciences, San Francisco, California, United States of America

CBU Cape Breton University, Sydney, Nova Scotia, Canada

CNC Canadian National Collection of Insects, Ottawa, Ontario, Canada

JCC Joyce Cook Collection, Carleton University, Ottawa, Ontario, Canada

JOC Jeffrey Ogden Collection, Truro, Nova Scotia, Canada

NSMC Nova Scotia Museum, Halifax, Nova Scotia, Canada

NSNR Nova Scotia Department of Natural Resources, Shubenacadie, Nova Scotia, Canada

RWC Reginald P. Webster Collection, Charter's Settlement, New Brunswick, Canada

SMU Saint Mary's University, Halifax, Nova Scotia, Canada

\section{Individual species treatments}

\section{Amara communis (Panzer, 1797)}

\section{Distribution and bionomics: Palearctic region}

In the Palearctic region, $A$. communis is found throughout most of Europe from Scandinavia south to Spain, Italy, Asia Minor, and the Caucasus and east across Siberia to the Kamchatka Peninsula (Lindroth 1945). In Europe it is typically found in moderately dry soil in lowland meadows and forests and feeds on 
plant seeds. It is capable of flight (Larochelle and Larivière 2003).

\section{Distribution and bionomics: North America}

The known distribution of $A$. communis in North America is represented in Figure 1 (closed circles). One hundred and thirty-four specimens were examined. The distribution has been extended to encompass all three Maritime Provinces (New Brunswick, Nova Scotia, and Prince Edward Island). Sites where it has been found include Brier Island (JOC), Bellisle, Avonport (ACNS), New Minas, Starrs Point, Wolfville (NSMC), Bible Hill (CBU), and Burnside (SMU), Nova Scotia; Rollo Bay (ACPE), Prince Edward Island; and Saint John (RWC), West Quaco, and Waterside (CNC and NSMC), New Brunswick.

The inset map shows additional records outside of the Maritime Provinces, from the Gaspé Peninsula in Quebec (June-July 1990, Parc national de la Gaspésie, Gaspé-Ouest, Quebec, L. Lesage; CNC) and in Connecticut, United States of America (1989, 2.5 miles northeast of Oxford, New Haven Co., Connecticut; CAS).

The earliest collection dates are from 1988 (Larochelle and Larivière 2003). A large series (25 specimens) was collected in 1991 by I.A. Pearsall in the Annapolis Valley of Nova Scotia as part of a study of the ground beetles of apple orchards (Pearsall and Walde 1994), but the identity of the species was not recognized at the time. In terms of seasonal phenology, the earliest records are from 22 April (2003, Burnside, Nova Scotia, C. Cormier; SMU) while the latest are from 31 August (2001, Rollo Bay, Prince Edward Island, C. Noronha).

In Canada A. communis has been collected in a variety of habitats including coastal meadows, hayfields, apple orchards, potato fields, pastures, open meadows, grassy ditches, and mixed forests. Most of these habitats contain significant sources of graminaceous seeds, reflecting the known feeding preferences of the species. An unusual series of specimens (10) was collected by C. Cormier in both forested and open habitats in Burnside, Nova Scotia, in pitfall traps associated with decomposing pigs as part of a study in forensic entomology. It is not clear whether the specimens were attracted to the decomposing carrion or were simply incidentally captured in such locations.

\section{Modes of introduction}

Bousquet (1992) did not favour dry ballast as the method of introduction of $A$. communis because the species appeared to have been introduced recently. Indeed, the considerable collections of Brown (1940, 1950, 1967), focusing on introduced species, and Lindroth (1954), focusing on ground beetles, did not include A. communis, which would seem to indicate that the species was not present at the time of their collecting. However, a closer examination of the sites reported by Lindroth (1954) reveals that he did not collect at all along the Bay of Fundy (or in New Brunswick or Prince Edward Island). Similarly, Brown collected little along the Bay of Fundy or in the Annapolis Valley, and not at all in any of the localities where A. communis has subsequently been found. Thus, the apparently recent detection of this species might instead be an artifact of the historical collecting record.

From Figure 1 it is clear that $A$. communis is widely distributed in the Maritime Provinces, particularly around the perimeter of the Bay of Fundy, where all but two of the recorded sites are located. A notable feature of the distribution of these records is that they are all (with the exception of New Minas, which is $8 \mathrm{~km}$ from the Minas Basin) from localities on the seacoast. Some of these sites (Rollo Bay, Prince Edward Island; Bible Hill, Bellisle, Starrs Point, Wolfville, and New Minas, Nova Scotia) are in areas of agricultural activity, while others (West Quaco and Waterside, New Brunswick; Brier Island and Avonport, Nova Scotia) are not. Furthermore, some of these sites were formerly important fishing centres (Westport on Brier Island) and (or) had thriving shipbuilding industries (St. Martins, adjacent to West Quaco, and Waterside; Avonport). Burnside, Nova Scotia (on the eastern shore of Halifax Harbour), and Saint John, New Brunswick, are seaports with a significant history of transatlantic commercial activity. Bellisle Marsh is on the former tidal estuary of the Annapolis River (now behind a tide control dam), Starrs Point and Wolfville are on the Minas Basin, and Bible Hill is at the head of Cobequid Bay - all areas that have experienced marine traffic.

Indeed, there is a notable lack of records from inland locations, even in areas of agricultural activity and where ground beetle faunas have been investigated (C.G. Majka, unpublished data). This coastal distribution would thus seem to be indicative of introductions via 
Fig. 1. Distributions of Amara communis and Bembidion femoratum in North America.

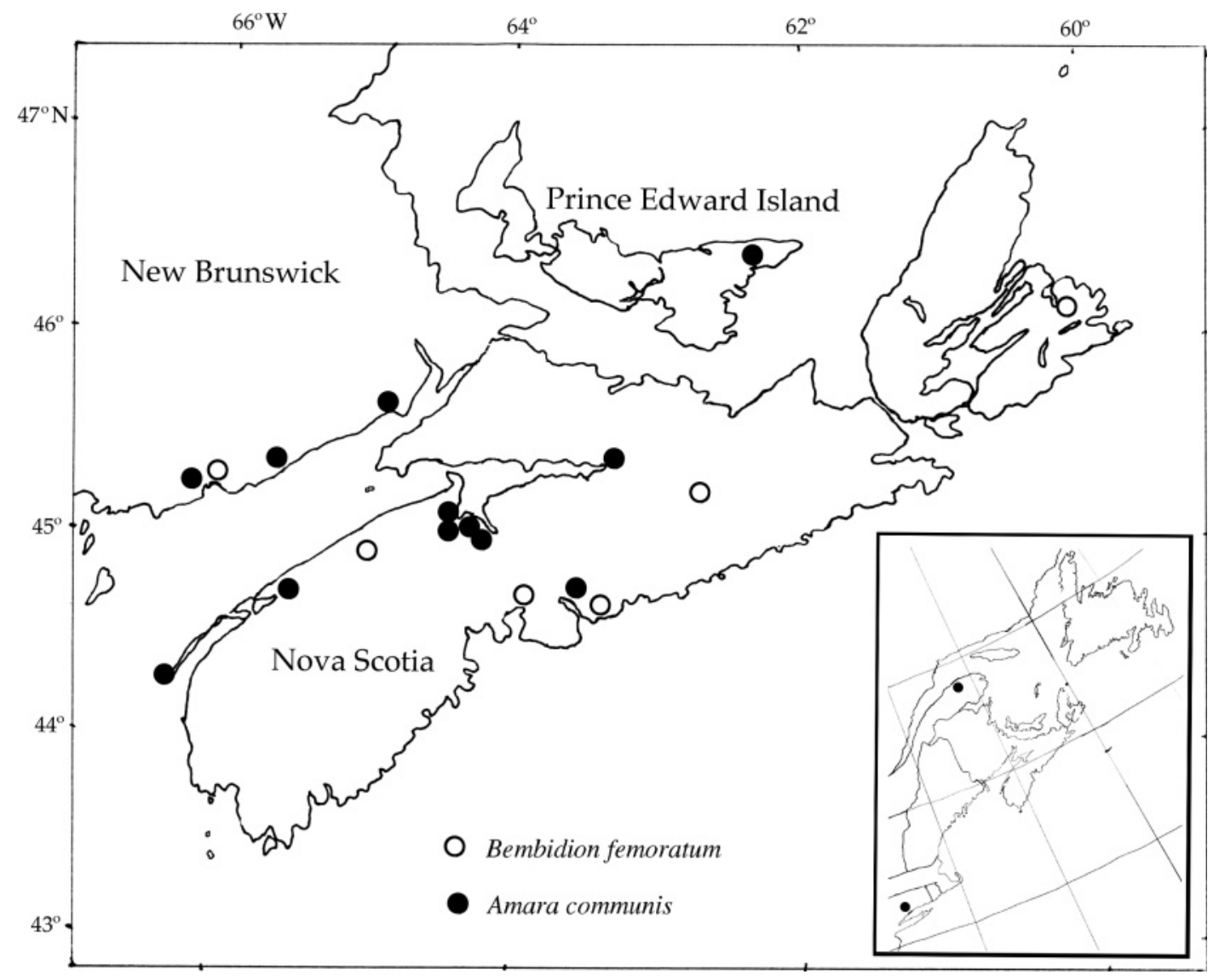

the marine trade, perhaps through dry ballast as advanced by Brown (1950) and Lindroth (1957). At Appledore in North Devon, one of seven locations in Great Britain investigated by Lindroth (1957), A. communis was found at sites where there are historical records of ballast being loaded on to ships bound for Atlantic Canada.

On the other hand, a number of the sites are agricultural or have experienced significant agricultural activity; hence, introduction in association with nursery stock cannot be excluded. Majka and Klimaszewski (2004) argued that the carabid Dromius fenestratus (Fabr., 1794) was introduced to Nova Scotia in association with the planting of tree nursery stock.

The records from the Gaspé and Connecticut clearly indicate multiple points of entry into North America, since these areas are significantly disjunct from the Maritime Provinces. Indeed, the records from Prince Edward Island might also indicate a separate introduction, either directly from European sources or from other sites in the Maritime Provinces. Thus, the current distribution of this species may represent a composite of historical introductions in association with dry ballast, more recent introductions in association with nursery stock, and even more recent natural dispersion. Mikkola and Lafontaine (1994) discussed modern shipping containers as possible vectors of introduced moths, a source which could be a factor in recent introductions of beetles as well.

\section{Bembidion femoratum Sturm, 1825}

\section{Distribution and bionomics: Palearctic region}

Bembidion femoratum is found throughout Europe, from Scandinavia south and west to Spain, east across Europe and Asia Minor, and across Siberia to the Lena River (Lindroth 1945). In Europe it is found primarily near water, notably along river banks, on clay or clay 
mixed with sand, silt, or gravel amongst sparse vegetation. It is also found in gravel and clay pits, along roadsides, and in cultivated fields (Lindroth 1985).

\section{Distribution and bionomics: North America}

The known distribution of $B$. femoratum in North America is represented in Figure 1 (open circles). Newly reported specimens have been taken in Melvern Square, Annapolis Co., Nova Scotia (24 June 1992, E. Georgeson; NSNR), Liscomb Game Sanctuary near Trafalgar, Guysborough Co., Nova Scotia (19 July 1992, S. and J. Peck; JCC), and on the Indian Lake road, north of Upper Tantallon, Halifax Co., Nova Scotia (17 July 1992, S. and J. Peck; JCC). The first specimen was collected in a light trap in an agricultural area not far from the Annapolis River. The latter two specimens were collected on forest roads near lakes or river courses in the evening using a car net, which collects flying insects. Specimens from Saint John, New Brunswick, and Sydney, Nova Scotia, were collected under rocks and debris on moderately moist, clayey soil in abandoned fields (Bousquet 1992).

\section{Modes of introduction}

The mode of introduction of $B$. femoratum is far less clear than that of $A$. communis. Bousquet (1992) suggested the possibility of importation in association with nursery stock. Although the discovery of this species in abandoned fields in Saint John and Sydney would be consistent with this explanation, both sites are also major seaports with a long history of shipping and many records of imported Coleoptera. Lindroth (1957), however, did not find $B$. femoratum at any of the British ballast sites that he surveyed. Lawrencetown is a small coastal village on a sandspit between Lawrencetown Lake and the Atlantic Ocean without obvious shipping or agricultural connections. It is, however, only $12 \mathrm{~km}$ away from significant port facilities at Eastern Passage in Halifax Harbour and the airport at Canadian Forces Base Shearwater.

The specimens of $B$. femoratum collected near Trafalgar in the Liscomb Game Sanctuary and on the Indian Lake road north of Upper Tantallon are surprising. Both of these sites (particularly the former) are relatively isolated, forested locations distant from agricultural or shipping areas or any anthropogenic activities. These locations, and the fact that both specimens were captured in flight, might indicate that the specimens were aerially dispersing. The specimen collected at Melvern Square was captured in a light trap. This site is situated in an agricultural area where importation of nursery stock could be a factor. However, another possible explanation also presents itself.

Melvern Square is less than $3 \mathrm{~km}$ from Canadian Forces Base Greenwood, the home of Canada's largest air force wing on the east coast and a significant airbase and international training facility since its establishment in 1942. The British Royal Air Force No. 36 Operational Training Unit (OTU) was based there (later becoming Royal Canadian Air Force No. 8 OTU), with a staff of almost 1500, and over 140 aircraft operated from there. Such considerable transatlantic activity from 1942 to 1945 could have provided many opportunities for inadvertent introduction of species. The aircraft themselves can be a vector of introduction. I have examined specimens of Phyllophaga hirsuta (Knoch, 1801) (Scarabaeidae) removed from the air intake manifolds of Sea King helicopters at Canadian Forces Base Shearwater (NSMC). This species is not present in Atlantic Canada and, indeed, the aircraft had just returned from maneuvers in Upper Canada.

\section{Conclusions}

Nova Scotia is well known as a springboard for adventive species of Carabidae that have subsequently colonized other parts of the continent. The Palearctic species Amara aulica (Panzer, 1796) and Amara bifrons (Gyllenhal, 1810) were both first recorded on Cape Breton Island in Nova Scotia in 1929 and are now widely found in Atlantic Canada, Quebec, and northern New England. The Palearctic species Bembidion bruxellense Wesmael, 1835 was first detected in Nova Scotia in 1910 in Port Medway, while Bembidion properans (Stephens, 1828) was first found in North America in 1947 in Dartmouth, Nova Scotia. Both species have subsequently spread to other parts of the region and beyond (Fall 1934; Lindroth 1954; Bousquet and Larochelle 1993). The apparently increasing range of both $A$. communis and $B$. femoratum in Atlantic Canada indicates that these species may continue to expand their distribution in North America.

Current concerns in relation to potentially invasive adventive species of beetles such as Tetropium fuscum (Fabr., 1787) (Smith and 
Humble 2000), Popillia japonica Newman, 1838 (LeBlanc 2002), and Meligethes viridescens (Fabr., 1787) (Mason et al. 2003) in the Maritime Provinces indicate the need for further biodiversity and biosystematics research as well as ongoing monitoring programs to ensure that invasive species can be recognized and detected.

\section{Acknowledgments}

Many thanks to K. Aikens (Cape Breton University), Y. Bousquet (Agriculture and Agri-Food Canada, Ottawa), J. Cook (Carleton University), C. Cormier (Saint Mary's University), C. D'Orsay (Cape Breton University), F. Hieke (Institute of Systematic Zoology, Berlin), S. Lemoine (Acadia University), D. McCorquodale (Cape Breton University), C. Noronha (Agriculture and Agri-Food Canada, Charlottetown), J. Ogden (Nova Scotia Department of Natural Resources), S. Rigby (Agriculture and Agri-Food Canada, Kentville), C. Sheffield (Agriculture and Agri-Food Canada, Kentville), and R. Webster for their assistance in providing loans of specimens and data. Two anonymous reviewers read an earlier version of the manuscript and provided many constructive suggestions. Thanks are also offered to my colleagues at the Nova Scotia Museum, C. Ewing and A. Hebda, for their continuing support and encouragement. This work was assisted by a research grant from the Nova Scotia Museum of Natural History.

\section{References}

Bousquet, Y. 1992. Bembidion femoratum Sturm and Amara communis (Panzer) (Coleoptera: Carabidae) new to North America. Journal of the New York Entomological Society, 100(3): 503-509.

Bousquet, Y., and Larochelle, A. 1993. Catalogue of the Geadephaga (Coleoptera: Trachypachidae, Rhysodidae, Carabidae including Cicindelini) of America north of Mexico. Memoirs of the Entomological Society of Canada, 167.

Brown, W.J. 1940. Notes on the American distribution of some species of Coleoptera common to the European and North American continents. The Canadian Entomologist, 72: 65-78.

Brown, W.J. 1950. The extralimital distribution of some species of Coleoptera. The Canadian Entomologist, 82: 197-205.

Brown, W.J. 1967. Notes on the extralimital distribution of some species of Coleoptera. The Canadian Entomologist, 99: 85-93.
Evans, J.D. 1899. List of Coleoptera from Halifax, N.S. The Canadian Entomologist, 31: 320-321.

Fall, H.C. 1934. A new name and other miscellaneous notes. Pan-Pacific Entomologist, 10: 171-174.

Hoebeke, E.R., and Wheeler, A.G. $1996 a$. Meligethes viridescens (F.) (Coleoptera: Nitidulidae) in Maine, Nova Scotia, and Prince Edward Island: diagnosis, distribution, and bionomics of a Palearctic species new to North America. Proceedings of the Entomological Society of Washington, 98: 221-227.

Hoebeke, E.R., and Wheeler, A.G. 1996b. Adventive lady beetles (Coleoptera: Coccinellidae) in the Canadian Maritime Provinces, with new eastern U.S. records of Harmonia quadripunctata. Entomological News, 107: 281-290.

Hoebeke, E.R., and Wheeler, A.G., Jr. 2000. Telmatophilus typhae (Fallén) (Coleoptera: Cryptophagidae), a Palearctic cattail specialist established in the Canadian Maritime Provinces. Proceedings of the Entomological Society of Washington, 102: 398-402.

Hoebeke, E.R., and Wheeler, A.G., Jr. 2003. Sphaeroderma testaceum (F.) (Coleoptera: Chrysomelidae), a Palearctic flea beetle new to North America. Proceedings of the Entomological Society of Washington, 105: 990-994.

Johnson, P.J. 1990. Notes on the naturalization of two species of European Byrrhidae (Coleoptera) in North America. Journal of the New York Entomological Society, 98(4): 434-440.

Jones, J.M. 1869. Nova Scotia Coleoptera: Part I. Transactions of the Nova Scotia Institute of Natural Science, 2: 141-155.

Kirby, W. 1837. Fauna boreali-Americana or the Zoology of the northern parts of British America, containing descriptions of the objects of natural history collected on the late northern land expeditions, under the command of Captain Sir John Franklin, RN, by John Richardson. Vol. 4. Fletcher, Norwich, England.

Larochelle, A., and Larivière, M.-C. 2003. A natural history of the ground-beetles (Coleoptera: Carabidae) of America north of Mexico. Pensoft, Sofia, Bulgaria.

LeBlanc, N. 2002. CFIA program to eradicate Japanese Beetle in Halifax. Canadian Food Inspection Agency news release, March 25, 2002. Available from http://www.inspection.gc.ca/english/corpaffr/ newcom/2002/20020325e.shtml [cited 1 August 2005].

Lindroth, C.H. 1945. Die Fennoskandischen Carabidae: Eine Tiergeographische Studie. I. Spezieller Teil. Kungliga Vetenskapsakademien Vitterh. Samhälles Handlingar, Sweden B, 4: 1-709.

Lindroth, C.H. 1954. Carabid beetles from Nova Scotia. The Canadian Entomologist, 86: 299-310.

Lindroth, C.H. 1955. The carabid beetles of Newfoundland. Opuscula Entomologica Supplementum, 12. 
Lindroth, C.H. 1957. The faunal connections between Europe and North America. Almqvist and Wiksell, Stockholm, Sweden.

Lindroth, C.H. 1963. The fauna history of Newfoundland illustrated by carabid beetles. Opuscula Entomologica Supplementum, 23.

Lindroth, C.H. 1985. The Carabidae (Coleoptera) of Fennoskandia and Denmark. Fauna Entomologica Scandinavica. Vol. 15. Part 1. Leiden, Copenhagen.

Majka, C.G., and Klimaszewski, J. 2004. Phloeocharis subtilissima Mannerheim (Staphylinidae: Phloeocharinae) and Cephennium gallicum Ganglbauer (Scydmaenidae) new to North America: a case study in the introduction of exotic Coleoptera to the port of Halifax, with new records of other species. Zootaxa, 781: 1-15.

Mason, P.G., Olfert, O., Sluchinski, L., Weiss, R.M., Boudreault, C., Grossrieder, M., and Kuhlmann, U. 2003. Actual and potential distribution of an invasive canola pest, Meligethes viridescens (Coleoptera: Nitidulidae), in Canada. The Canadian Entomologist, 135: 405-413.
Mikkola, K., and Lafontaine, J.D. 1994. Recent introductions of riparian noctuid moths from the Palearctic region to North America, with the first report of Apamea unamis (Hübner) (Noctuidae: Amphipyrinae). Journal of the Lepidopterists' Society, 48(2): 121-127.

Pearsall, I.A., and Walde, S.J. 1994. Parasitism and predation as agents of mortality of winter moth populations in neglected apple orchards in Nova Scotia. Ecological Entomology, 19: 190-198.

Smith, G.A., and Humble, L.M. 2000. The brown spruce longhorn beetle. Exotic Forest Pest Advisory 5. Canadian Forest Service, Victoria, British Columbia.

Spence, J.R., and Spence, D.H. 1988. Of ground-beetles and men: introduced species and the synathropic fauna of western Canada. Memoirs of the Entomological Society of Canada, 144: 151-168.

Wheeler, A.G., and Hoebeke, E.R. 1994. First records from the Canadian Maritime provinces of three European insects injurious to ornamental plants. Proceedings of the Entomological Society of Washington, 96(4): 749-756. 